\title{
Microalgae use in animal nutrition
}

\author{
Uso de microalgas na nutrição animal \\ Uso de microalgas en nutrición animal
}

\begin{abstract}
Looking for alternative sources in animal nutrition, microalgae began to be explored, gaining space in commercial production. The aim of this review is to present available information about the use of microalgae in animal nutrition, as well as its effect and applications. Many microalgae are important sources of polyunsaturated fatty acids (PUFA), mainly eicosapentaenoic acid (EPA) and docosahexaenoic acid (DHA). These PUFA is poorly synthesized by animals, so they should be included in their diet. In addition, they are a rich source of almost all of the important minerals as well as vitamins. Additionally, some microalgae generally have a high protein content and high digestibility. In this context, microalgae already available on the market, become an alternative replacing conventional ingredients. To our knowledge, the use of small amounts of microalgae biomass in the feed can benefit the physiology of the animals, improving the immune response, resistance to diseases, antiviral and antibacterial action, intestinal function, and stimulation of probiotic colonization. In general, the addition of these compounds to the diets of animals enhances their overall health and immune status, productivity, and the quality and stability of the resulting animal products. Although the use of microalgae is increasingly directed towards many types of animals: cats, dogs, ornamental fish, horses, poultry, swine, sheep, and cow, studies still need to be explored.
\end{abstract}

Keywords: Eicosapentaenoic acid; Docosahexaenoic acid; General health; Sustainability.

\section{Resumo}

Em busca por fontes alternativas na nutrição animal, as microalgas começaram a ser exploradas, ganhando espaço na produção comercial. O objetivo desta revisão é apresentar as informações disponíveis sobre o uso de microalgas na alimentação animal, bem como seu efeito e aplicação. Muitas microalgas são fontes importantes de ácidos graxos poliinsaturados (PUFA), principalmente ácido eicosapentaenóico (EPA) e ácido docosahexaenóico (DHA). Esses PUFA são mal sintetizados pelos animais, por isso devem ser incluídos na dieta diária. Além disso, eles são uma fonte rica em quase todos os minerais importantes, além de serem abundantes em vitaminas. Além disso, algumas microalgas geralmente apresentam alto teor de proteínas, além de alta digestibilidade. Nesse contexto, as microalgas já disponíveis no mercado, passam a ser uma alternativa em substituição aos ingredientes convencionais. Até onde sabemos, a utilização de pequenas quantidades de biomassa de microalgas na ração pode beneficiar a fisiologia dos animais, melhorando a resposta imune, resistência a doenças, ação antiviral e antibacteriana, função intestinal e estímulo à colonização probiótica. Em geral, a adição desses compostos às dietas dos animais melhora a saúde geral e o estado imunológico, a produtividade e a qualidade e estabilidade dos produtos animais resultantes. Embora o uso de microalgas seja cada vez mais direcionado a diversos tipos de animais: gatos, cães, peixes ornamentais, cavalos, aves, suínos, ovelhas e vacas, estudos ainda precisam ser explorados.

Palavras-chave: Ácido eicosapentaenóico; Ácido docosahexaenóico; Saúde geral; Sustentabilidade.

\section{Resumen}

En la búsqueda de fuentes alternativas en la nutrición animal, se comenzaron a explorar las microalgas, ganando terreno en la producción comercial. El objetivo de esta revisión es presentar la información disponible sobre el uso de microalgas en la nutrición animal, así como su efecto y aplicación. Muchas microalgas son fuentes importantes de ácidos grasos poliinsaturados de cadena larga (AGCL), principalmente ácido eicosapentaenoico (EPA) y docosahexaenoico (DHA). Estos AGCL son mal sintetizados por los animales, por lo que deben incluirse en la dieta diaria. Además, son una rica fuente de casi todos los minerales fundamentales, también de ser abundantes en 
vitaminas. Adicionalmente, algunas microalgas suelen tener un alto contenido de proteínas, además de una alta digestibilidad. En este contexto, las microalgas ya disponibles en el mercado, se convierten en una alternativa a la sustitución de ingredientes convencionales. Hasta donde sabemos, el uso de pequeñas cantidades de biomasa de microalgas en la alimentación puede beneficiar la fisiología de los animales, mejorando la respuesta inmune, la resistencia a enfermedades, la acción antiviral y antibacteriana, la función intestinal y estimulando la colonización prebiótica. En general, la adición de estos compuestos a las dietas de los animales mejora la salud general y el estado inmunológico, la productividad y la calidad y estabilidad de los productos animales resultantes. Aunque el uso de microalgas está cada vez más dirigido a diferentes tipos de animales: gatos, perros, peces ornamentales, caballos, aves de corral, cerdos, ovejas y vacas, aún quedan por explorar estudios.

Palabras clave: Ácido eicosapentaenoico; Ácido docosahexaenoico; Salud general; Sustentabilidad.

\section{Introduction}

Microalgae are important constituents of many ecosystems, are pivotal for the global food chain primary production (Koller, et al. 2014). Thus, microalgae have the potential to produce important energy compounds from their efficiency in harnessing solar energy, surpassing even higher organisms such as plants. These characteristics led to the development of constant research on the use of this biomass for food and feed, as well as for biofuels (Chew, et al. 2017).

Searching for alternative sources in animal nutrition, microalgae began to be explored, gaining space in commercial production due to their great potential in $\omega-3$ production, and its nutritional characteristics. In addition, they show rapid growth and can convert sunlight and carbon dioxide into biomass during photosynthesis (Adarme-Vega, et al. 2012). Along with the ecological benefit, several species of microalgae have high nutritional value and, at the same time, are rich in important bioproducts, source of almost all minerals such as copper, iodine, iron, potassium, and zinc, as well as vitamins (Christaki, et al. 2011).

In general, the inclusion of microalgae and biomass in animal feed can provide vitamins, essential amino acids, polysaccharides, $\omega-3$ and $\omega-6$ fatty acids, minerals, and pigmentation agents for skin and egg yolks (Drewery, et al. 2014). Besides that, some microalgae generally have a high protein content and a high digestibility (Souza, et al. 2019; Sarker, et al. 2016), what makes them excellent options to be used in animal feed. The lipid content of microalgae cells can reach up to $90 \%$ in dry matter. In this context, microalgae already available on the market become an alternative (Souza, et al. 2019) to replace conventional fonts of lipids.

Researches have been made to find strategies to scale up highly efficient and cost-effective microalgae production and assess its application in animal health and performance (Souza, et al. 2019; El-Bahr, et al. 2020; Souza, et al. 2020). Despite their potential use in animal feeding, their applications are still limited. Based on that, this review paper focus on the use of microalgae for animal feeding to provide complete information on their effects and limitations.

\section{Microalgae Characteristics: Application in Animal Nutrition}

Up to $30 \%$ of the current world production of the algae is intended for animal feed applications. And the predominant species are: Schizochytrium sp., Chlorella sp., Arthrospira sp., Isochrysis sp. and Porphyridium sp. The use of small amounts of microalgae biomass in the animal feed can benefit the animals' physiology, improving the immune response, resistance to diseases, antiviral and antibacterial action, intestinal function, and the stimulation of probiotic colonization (Becker, 2004).

Microalgae are an enriched source of a wide metabolites range suitable for animal feed, such as proteins, carbohydrates, lipids (Table 1), vitamins, minerals, and other organic compounds (Andrade, et al. 2018). It is important to note that the composition of the microalga is widely variable due to the genus, species, and cultivation conditions (Spolaore, et al. 2006; Venckus, et al. 2017). 
Table 1: Chemical composition of some microalgae explored in animal nutrition (\% in dry matter).

\begin{tabular}{lccc}
\hline Microalgae species & Crude protein (\%) & Lipids (\%) & Carbohydrates (\%) \\
\hline Chlorella vulgaris & $51-58$ & $14-22$ & $12-17$ \\
Haematococcus pluvialis & 48 & 15 & 27 \\
Dunaliella salina & $39-61$ & $14-20$ & $14-18$ \\
Spirulina máxima & $60-71$ & $4-9$ & $8-14$ \\
Isochrysis galbana & $50-56$ & $12-14$ & $10-17$ \\
Diacronema vikianum & 57 & 6 & 32 \\
\hline
\end{tabular}

Source: Adapted to Christaki, et al. (2011).

Many microalgae are important sources of PUFA, mainly eicosapentaenoic acid (EPA) and docosahexaenoic acid (DHA), as these organisms have an alfa-4-desaturase enzyme, which directly transforms 22:5 $\omega$-3 into DHA (Appolinário, et al. 2011). These PUFA cannot be synthesized by humans or animals, so they should be included in the daily diet (Simopoulos, 2002). It is known that these acids are valuable for animals and humans' health because they contribute to the production of prostaglandins, thromboxanes, etc., which are biologically active substances that are important for the reduction of cholesterol and triglycerides in the blood, as well as it helps with prevention of cardiovascular diseases, atherosclerosis, skin diseases and arthritis (Simopoulos, 2002; Gouveia, et al. 2008).

Algae such as Dunaliella sp., Crythecodinium conquistii, Nannochloropsis sp., Phaeodactylum tricornutum, Schizochytrium limacinum, and Thraustochytrium can accumulate between 30 and 40\% of DHA and EPA. Some strains of algae have a high oil content, and the percentage of total lipids then varies between 30 to $70 \%$ of the dry matter (AdarmeVega, et al. 2012). Some species of microalgae can produce these fatty acids in quantities varying not only between different species but also between different phases of development (Spolaore, et al. 2006).

The synthesis of fatty acids carried out by microalgae occurs in the chloroplast stroma. The synthesis of DHA, in general, is established utilizing anaerobic polyketide synthase (APS), in which the low dissolved oxygen favors the production of this fatty acid (Chang, et al. 2013). The metabolic synthesis pathway produces a chain of 16 or 18 carbons, used for the formation of organelles, membranes, and triacylglycerols, which are incorporated in lipids and accumulates according to environmental conditions (Adarme-Vega, et al. 2012).

The other constituents of dry microalgae biomass are protein, with high total content, balanced amounts of essential amino acids, and a similar composition to animal proteins (Becker, 2004; Kotrbáček, et al. 2015). Due to the high protein content of some microalgae, it is considered an unconventional source of this nutrient (Becker, 2007). In fact, unlike other plants, most microalgae contain essential amino acids that cannot be synthesized for humans and animals (Gouveia, et al. 2008). A study demonstrates that the content of amino acids: lysine, methionine, tryptophan, threonine, valine, histidine, and isoleucine, in some microalgae is comparable to that of egg or soy (Becker, 2007).

Microalgae are also an important source of nearly all the important vitamins such as tocopherols, ascorbic acid, B1, B2, B6, B12, folic acid, nicotinic acid, biotin and so on as well as macro minerals ( $\mathrm{Na}, \mathrm{K}, \mathrm{Ca}$ and $\mathrm{Mg}$ ) and micro minerals (Fe, Zn, Mn, and Cu) (Fabregas \& Herrero, 1990; Becker, 1994; Spolaore, et al. 2006; Christaki, et al. 2011). Likewise, these organisms have their vast range of pigment content like chlorophylls, carotenoids, phycobiliproteins, xanthophylls and astaxanthin (Aki, et al. 2003; Roy \& Pal, 2015). These antioxidants are substances that protect cells from free radicals. As already mentioned, the antioxidants of microalgae have a stronger effect than vitamin $\mathrm{E}$, but weaker than synthetic antioxidants such as butylated hydroxytoluene or butylated hydroxyanisole (Natrah, et al. 2007). But, as consumers prefer natural products, these microalgae antioxidants can be used in functional foods. For some authors, the nitrogen content in the culture medium is 
a determining factor in the production of these lipophilic substances (Hong, et al. 2011). Therefore, it is possible to increase the production of carotenoids as microorganisms that act as natural antioxidants in feed products.

Several types of unicellular microalgae, especially Chlorella and Spirulina species, are excellent sources of immunoregulatory polysaccharides, such as $\beta$-glucan, $\beta$ carotene, and vitamin B12 that play a pivotal role in inflammatory and immune responses in animals and humans (Mason, 2001). Moreover, Chlorella sp. (CLV) can promote the activity of macrophages and immune cells to increase its production of $\gamma$-interferon protein, which can protect the body against infections. Therefore, Chlorella sp. can stimulate the ability of the immune system to fight against pathogens and foreign proteins (Abdelnour, et al. 2019).

The use of microalgae has increased for several types of animals: cats, dogs, ornamental fish, horses, poultry, swine, sheep, and cow (Spolaore, et al. 2006; Souza, et al. 2019). Despite that, studies on the inclusion of these organisms in animal nutrition still need to be explored.

\subsection{Dogs and cats}

Few studies evaluated the effects of the microalgae on the physiological and nutritional parameters of dogs and cats. As the conversion rate of alpha-linolenic acid (ALA, $\omega-3$ ) to DHA in these animals is inefficient, requiring supplementation via specific sources, microalgae became an alternative. The main microalgae assessed for inclusion in pet diets is Schizochytrium sp. These microalgae may be a promising source for DHA supplementation in diets since it has a high concentration of this fatty acid (approximately 20\%) readily available helping to delay the inflammations development (Souza, et al. 2019, Souza, et al. 2020).

DHA has a modulating effect on the regulators of the eicosanoids and cytokines synthesis active in the body's inflammatory processes (Wallace, et al. 2003). Also, they assist the neurological development of dogs (Heinemann, et al. 2005), and their effect on improving these animal's health has been proven (Stoeckel, et al. 2011; Souza, et al. 2019). The traditional sources of DHA used in dog diets are fish oils and derivatives. However, fish resources are unstable, as they depend on the season, climate, location, in addition to competing with human alimentation. This way, microalgae have been studied.

In cats, diets with increasing levels of $0.14 \%$ and $0.12 \%$ of the microalgae Schizochytrium sp. rich in DHA allowed positive effects on post-surgical recovery of neutered cats (Sheibel, 2016). Other studies have shown that the addition of 0.4\% of microalgae Schizochytium sp. in the diet as a source of DHA is palatable to dogs and increases the nutrients digestibility and metabolizable energy (ME). Also, it increases phagocytic cells concentration and the phagocytosis intensity of monocytes in the blood, and exhibits superior oxidative stability to anchovy oil (Souza, et al. 2019). According to Souza, et al. (2020) the inclusion of dietary microalgae Schizochytrium sp. reduced the area of gingivitis in dogs, because DHA acts as a substrate of endogenous lipid mediators involved in the resolution phase of inflammation in periodontal disease (Sete, et al. 2013).

It was also reported that the use of Schizochytrium sp. in dog diets in conjunction with dietary supplementation of antioxidants, including $\beta$-carotene and tocopherol, has been associated with improved cognitive function on the animals (De Rivera, et al. 2005). It is important to note that antioxidant activities vary between microalgae (Li, et al. 2007).

Another interesting study was conducted aiming to evaluate the use of Schizochytrium sp. in the diet of senescent canines. The authors concluded that there were an association between consumption of a diet fortified with biomass rich in DHA and a greater support for healthy brain function (Hadley, et al. 2017).

When analyzing 18 types of algae for use in dogs and cats' feed as alternative sources of taurine, it was found that some species of microalgae can be practical alternatives to traditional proteins and supplemental taurine sources in pet food. However, the authors have not conducted tests on animals (McCusker, et al. 2014). 
Neto, et al. (2010) analyzed the use of seaweed meal (Lithothamnium calcareum) as a mineral supplement in bone consolidation of cortical autograft in dogs. After clinical evaluations, it was concluded that supplementation based in this microalga contributed to a better healing performance in treated animals.

Another interesting advantage about the use of microalgae in diets for dogs and cats is related to the consumers search for vegetarian and vegan diets, in which the microalgae can be used in the formulation to help balancing the nutrients of these diets and favor marketing in the products sale.

\subsection{Poultry}

\subsubsection{Laying hens}

The commercial use of microalgae in the feed industry is appropriate in poultry nutrition (Becker, 2007). A study using a microalgae biomass for the enrichment of eggs from laying hens evaluated: P. tricornutum, Nannochloropsis oculata, I. galbana, and Chlorella fusca. The biomasses had different $\omega-3$ content. The results found that all 4 biomasses tested gave rise to increased levels of $\omega-3$ polyunsaturated fatty acids (PUFA) in the egg yolk; the highest values were observed in supplementation with Phaeodactylum sp. and Isochrysis sp. (mainly EPA and DHA) and the lowest enrichment was included in Chlorella, probably due to an ineffective conversion of ALA to DHA (Lemahieu, et al. 2013). However, the inclusion of 2 and $10 \%$ of Chlorella sp. in the laying hens diet led to an increase of linolenic acid and DHA in the egg yolk, with a simultaneous reduction of docosatetraenoic acid, especially in the microalgae inclusion level of 10\% (Grigorova, et al. 2006).

Dietary supplementation with microalgae Nannochloropsis sp. enriched the egg yolk with n-3 PUFA (especially DHA) and increased the yolk color score without adverse effects on egg performance and quality, indicating the practical feasibility of partial replacement of the egg yolk for soybean meal in the diet of laying hens (Wu, et al., 2019). The carotenoids concentration in the egg yolk was also increased by supplementation of Phaeodactylum sp., Isochrysis sp., and Nannochloropsis sp. A similar result was observed with the use of Spirulina sp. in the diet of laying hens (Carrillo, et al. 2008). It is important to pay attention to the color deviation of the egg yolk, as it can decrease the acceptability for consumers (Lemahieu, et al. 2013).

\subsubsection{Broilers}

According to Petrollli, et al. (2019) the inclusion of microalgae can be done appropriately in the broilers' nutrition. This supplementation in broiler diets enriches the $\omega$-3 fatty acids (DHA) content in the broiler's carcass (thigh and drumstick). The increase in body weight could be explained by the positive effect of DHA on the development of nervous tissue in the early phase of body development. The authors concluded that microalgae of the genus Schizochytrium sp. can be added to the diet without compromising the birds' development, to improve the fatty acid profile of the meat. An experimental trial supplementing the broilers diets with Aurantiochytrium limacinum observed an increased broiler breast and thigh meat DHA content, in addition to the overall $\omega-3$ PUFA content while reducing the $\omega-6 / \omega-3$ ratio to a more desirable level for human nutrition, improving meat quality and providing a safe and sustainable method of increasing $\omega-3$ PUFA consumption for human population (Keegan, et al. 2019).

Another research to evaluate growth performance and meat quality in broiler chickens demonstrated that the inclusion of microalgae Amphora coffeaformis has a positive effect on performance, antioxidant status, and meat quality of breast muscle in broilers (El-Bahr, et al. 2020). Corroborating with this study, the use of Parachlorella sp. (0.5, 1.0 and $1.5 \%)$ can stimulate immunity without detrimental effects on the growth performance of pre-initial broilers (An, et al. 2020).

An, et al. (2016) concluded that meat color was enhanced by fermented Chlorella sp. (Oh, et al. 2015), which may be attributed to the better transfer of the active carotenoids contained in this microalga than those from other sources. However, 
the authors observed no effects on animal performance. In contrast to previous reports, Kotrbáček, et al. (2015) concluded that dietary supplementation with $0.5 \%$ Chlorella sp. biomass had no impact on the final body weight of broilers.

Studies of the use of microalgae in broilers on their intestinal microbiota population have been explored (Zheng, et al. 2012). The presence of useful bacteria in the intestinal tract in significantly increased amounts can aid in the digestion and absorbance of feed nutrients, favoring the intestinal functionality. Choi, et al. (2017) suggested that supplementation of broilers diets with Chlorella sp. or different concentrations of $E$. coli-fermented liquor (EFL) could result in a numeric difference in their excreta microflora composition involving Lactobacillus sp. and E. coli compared to the flora of untreated animals. Besides, the amount of faecal ammonia generated by Chlorella treated chicks was lower by $7.1 \%$ than that generated by control broilers.

The effect of Spirulina (Arthrospira platensis), individually and in combination with exogenous enzymes suggested that Spirulina sp. proteins impair the nutritive value of microalga for broilers through an increase in digesta viscosity and a lower digestibility, as a consequence of their proteolytic resistance to the broiler endogenous peptidases. In general, the meat quality characteristics appear to be unaffected, neither by Spirulina sp. nor by enzymes (Pestana, et al. 2020).

\subsection{Ruminants}

In recent years, microalgae were used in the ruminants' diets to nutritionally enrich their products, in particular meat and milk, with $\omega-3$. Becker, (2007) and Altomonte, et al. (2018) points out that ruminants are suitable models for feeding with microalgae, as they can digest cell wall organisms that are often not processed.

The microalga supplementation for ruminants is an effective method for reducing saturated fatty acids (SFAs) and increasing concentrations of conjugated linoleic acid (CLA) and other PUFA in the ruminants' milk (Franklin, et al. 1999; Papadopouls et al. 2002). These changes in the fatty acid profile probably relate to changes in the rumen bacterial flora population (Toral, et al. 2012).

Dairy ewe's milk composition was affected in a trial by the dietary inclusion of microalgae Schizochytrium sp. The milk was enriched with PUFA and the ratio of $\omega-6: \omega-3$ was 2.5:4.5 (Papadopouls, et al. 2002). Similar results were observed by Kouřimská, et al. (2014) using microalgae $C$. vulgaris in dairy goat's diet. The authors affirm that the inclusion of microalgae in the diet results in fatty acids changes and improves the nutritional and health properties of milk. The production of milk with beneficial fatty acids may have a desirable impact on the consumers health. However, the response of dairy goats and ewe to freshwater microalgae supplementation is not very well known. When including microalgae in goat's dairy products, that is, yogurt and feta cheese, they also were enriched in polyunsaturated fatty acids compared to controls (Papadopoulos, et al. 2002).

In the diets of dairy cows, researchers have shown that the addition of microalgae (Schizochytrium sp.) resulted in increased levels of DHA and conjugated linoleic acid in milk fat, whereas saturated fatty acids were reduced (Franklin, et al. 1999). When monitored changes in fatty acids in rumen fluid of cattle fed a diet containing red microalgae Crypthecodinium cohnii, was observed that the percentage of SFA decreased when the diet was supplemented with microalgae. On the other hand, there was an increase in rumen CLA (Or-Rashid, et al. 2008).

Due to differences in the kinds and levels of supplementation, type of feed and composition of the diet, the different nutrient profiles among microalgae feedstuffs, and the duration of the experimental period, it is not easy to compare in the literature the relationship between the effects of quantitative milk production and the microalgae feeding (Altomonte, et al. 2018).

Nevertheless, when the supplementation of microalgae products is exceeded, feed ingestion decreases. And in cows fed unified, the intake decreases from 7 to $45 \%$ (Boeckaert, et al. 2008; Moate, et al. 2013). Although without showing a 
decrease in total feed consumption, some authors have detected qualitative changes in consumption. Particularly, the consumption decrease of the concentrate containing microalgae was balanced by higher consumption of silage (Lamminen, et al. 2017). When the evaluation was performed in cows, the maximum number of microalgae ingested with no effect on feed intake ranges from 4 to $79 \mathrm{~g}$ of microalgae $/ \mathrm{kg}$ of dry matter in the diet. It is important to note that this reduction effect depends on the type of food that was supplied together with the microalgae (Papadopoulos, et al. 2002; Moate, et al. 2011).

Da Silva, et al. (2016) evaluated the effects of partially replacing dietary ground corn with a microalgae meal from Prototheca moriformis (composed of de-oiled microalgae and soy hulls) in cow's diets. The researchers have observed that the microalgae in the diet increased the ether extract (EE) digestibility compared with the control diet. For the authors, the microalgae meal may partially replace ground corn in the diets of lactating cows without impairing the animal's performance.

Van Emon, et al. (2015) suggested that a blend of microalgae and soyhulls could replace corn in diets for beef cattle. These authors combined these ingredients to form a microalgae meal consisting of $570 \mathrm{~g} / \mathrm{kg}$ of microalgae and then evaluated this product up to $450 \mathrm{~g} / \mathrm{kg}$ of diet dry matter (DM) on the performance of growing steers. Positive effects were found in dry matter intake (DMI) and the average daily gain (ADG) of animals, supporting the viability of microalga as a feedstuff for ruminants.

Table 2: Main purposes of the microalgae use for ruminants.

\begin{tabular}{llr}
\hline Item & \multicolumn{1}{c}{ Use } & Authors \\
\hline Partial substitution of corn or & $\begin{array}{c}\text { Boeckaert, et al. 2008 } \\
\text { concentrate }\end{array}$ & Da Silva, et al. 2016 \\
& Added to the lipid supplementation & Toral, et al. 2010 \\
& & Stamey, et al. 2012 \\
Protein & Partial replacement of soy & Póti, et al. 2015 \\
& Rapeseed & Lamminen, et al. 2017 \\
Other nutritional properties & Enhance the antioxidant defense system & Tsiplakou, et al. 2018 \\
& and oxidant status of products & \\
\hline
\end{tabular}

Source: Adapted to Altomonte, et al. (2018).

Some hypotheses are related to the low palatability of the microalgae observed in studies with ruminants (Franklin, et al. 1999; Papadopoulos, et al. 2002; Lamminen, et al. 2017):

- Taste and odor of the microalgae;

- The physical structure of the feed, especially if the microalgae are dry and finely powdered. However, studies showed that the palatability could be improved by pelleting the diet (Lamminen, et al. 2017);

- The decrease in fiber digestibility, which is partly linked to the fermentable carbohydrates in the algae and to the small particle size which could have a negative influence on rumen $\mathrm{pH}$ (Stokes, et al. 2015);

- The disturbance of the rumen fermentation through the PUFA contained in the algae which could have toxic effects on the rumen microflora (Boeckart, et al. 2008). 
However, although palatability is a point taken into account in the studies, most authors found no influence on milk production, whether in cows or small ruminants, and no effect was reported in studies where reductions or changes in feed intake were observed (Franklin, et al. 1999; Papadopoulos, et al. 2002; Moate, et al. 2013; Silva, et al. 2016; Lamminen, et al. 2017).

The beneficial effects of some microalgae species on metabolic status and defense system of ruminants as well as on the oxidant status of products have been reported. In a study with goats that were fed $C$. vulgaris, was found higher superoxide dismutase activity in blood and milk, and higher catalase activities in the blood plasma in superoxide dismutase and catalase are among the main components of the intracellular antioxidant defense mechanisms which regulate reactive oxygen species accumulation within tissues, whereas enzyme lactoperoxidase in milk is related to the oxidation of lipids (Tsiplakou, et al. 2018). In this same study there was also a reduction of anoxidative stress biomarker (protein carbonyls) in milk.

Recent researches have shown that dietary fat supplements, may reduce rumen CH4 emissions (Beauchemin, et al. 2008; Moate, et al. 2011). In a study in vitro, was observed that high doses of DHA in incubation media reduced CH4 production by up to $80 \%$ (Fievez, et al. 2007). On the other hand, in an in vivo experiment, $\mathrm{CH} 4$ emissions (g/d) and $\mathrm{CH} 4$ yield (g/kg of DMI) were not decreased by the supplementary microalgae meal with high DHA content (Moate, et al. 2013). Thus, at doses that may be considered appropriate for supplementary feeding, DHA is not a potent inhibitor of methanogenesis. The depression in milk fat concentration associated with algal meal containing DHA feeding cows is not related to the formation of C18:2 cis-10, trans 12 in the rumen or mammary gland (Moate, et al. 2013).

Currently, the lack of knowledge on the feeding value of microalgae (e.g. protein degradability and ruminal passage kinetics) warrants further research on the utilization of microalgae in ruminant nutrition (Lamminen, et al. 2017).

\subsection{Swine}

Based on restrictions on the use of antibiotics as growth promoters in pig farming, the development of viable alternatives for both producers and consumers is the focus of several studies. An alternative found to improve animal performance without the use of conventional antimicrobials is the use of natural additives such as seaweed. They are potentially beneficial in animal production and performance, have no final product, and their use may be economically viable.

Microalgae are widely known for having substances of high biological value, such as PUFA, high levels of proteins, pigments, antioxidants, vitamins, and minerals (Christaki, et al. 2011). Spirulina sp. showed positive results in modulating the intestinal microbiota and stimulating the immune system (Bertoldi, et al. 2008). Among marine microalgae, mainly those of the genus Schizochytrium sp. are primary sources of DHA in the feed chain, therefore, it has been included in animal feed to improve the content of this fatty acid in animal products.

The supplementation of Schizochythrum sp. as a source of DHA in the pig diets can increase the amount of $\omega$-3 in the meat of these animals (Marriott, et al. 2002). Also, derivatives from Schizochytrium sp. demonstrated interesting results in terms of improving the nutritional value of pork meat, increasing DHA levels in both muscle and fat in the back of these animals (Sardi, et al. 2006). This may indicate potential health benefits for consumers, such as modulating the body's inflammatory and immune processes (Ajmone-Cat, et al. 2012).

Dietary microalgae supplementation has been proposed as a dietary protein supplement for pigs, and the use of Spirulina sp. in the diet of weaned piglets has shown that when pigs consumed $2 \%$ of microalgae they had an improvement in weight gain (Grinstead, et al. 2000). Another study observed a 9.26\% increase without daily weight gain and an improvement in carcass quality with Spirulina sp. supplementation in pigs aged 85 days (Simkus, et al. 2013).

Still, there are investigations on the prebiotic effects of Spirulina sp. which led to an increase of at least 10 times in the growth rate of Lactobacillus sp. compared to the control diet (Pulz \& Gross, 2004), what is very interesting for these 
animals, since prebiotics can act in the modulation of the intestinal microbiota, resulting in direct and indirect effects on the general health of their host as well as in the improvement of weight gain and feed efficiency.

\subsection{Aquaculture}

In general, aquaculture diets are based on conventional ingredients, such as fish oil and fish meal. Studies show that current exploitation to produce these aliments can negatively impact biodiversity and human food security (Smith, et al. 2011; Pikitch, et al. 2012), also, the price of these ingredients is historically high and OECD / FAO projections, (2013) show that it may increase further. These issues provide an impetus for the development of alternative ingredients for aquatic feed with high digestibility and nutrients, a value comparable to fish meal and fish oil for diets are being included in the literature. In this sense, marine microalgae are a nutrient source and a dietary supplement in the commercial cultivation of aquatic organisms and have been showing that they are potential ingredients.

Unlike terrestrial vegetable protein and the oil sources, microalgae have high levels of DHA and EPA, which are important for maintaining fish health, transmitting neurological, cardiovascular and anti-cancer benefits to humans (Brasky, et al. 2010). The microalgae I. galbana and Diacronema vlkianum are known by their ability to produce PUFA, mainly EPA and DHA (Gouveia, et al. 2008), and have been studied as an option for aquatic feeding with functional and performance characteristics.

DHA can assist the prevention of diseases in humans, in the development of the human brain membrane, and retina. It is interesting for pregnant women and for children, especially when the pregnancy reaches its final third, a period in which the development of the brain and retina is faster (Hakim, 2012).

The use of some species of microalgae in the fry's diets decreases their price to $50 \%$ and. To obtain greater nutritional value from biomass, it is common to use a combination of two or more species (Svircev, 2005). Sturgeon fed a diet based on a strain of the Spirulina genus outperformed animals fed diets based on fish meal. The inclusion of 50\% of Spirulina provided the highest growth rate, better feed conversion rate and higher protein efficiency (Palmegiano, et al. 2005).

A study with Nile tilapia (Oreochromis niloticus) fed diets containing Schizochytrium sp. microalgae, showed positive effects on final weight, weight gain, final biomass, biomass gain, and survival, improving the performance of these animals (Santos, et al. 2015). Still, with animals of the same species, Spirulina sp. showed better digestibility of crude protein and most essential substances (Sarker, et al. 2016).

Similar results were observed by Nandeesha, et al. (2001), using two species of Indian carp, catla (Catla catla), and rohu (Labeo rohita), those that were fed diets with Spirulina presented a significantly higher percentage of fat, showing the potential use of this microalgae for the performance of these animals, in terms of growth and carcass composition as a substitute for fish meal, partial or total or as a supplement of long-chain PUFA.

Also, marine microalgae can also be used as pigments in aquaculture feed for various species such: salmon, trout, shrimp, and lobster, that under intensive rearing conditions needs supplementation of carotenoids pigments in their diet to attain their characteristic muscle color. As seen in the literature, microalgae C. vulgaris (Chlorophyta and Volvocales) has been used to improve the pigmentation rates of rainbow trout (Gouveia, et al. 1998), golden (Gouveia, et al. 2002) and ornamental fish (Gouveia, et al. 2003; Sun, et al. 2012; Kouba, et al. 2013).

Coloring plays an important role in gaining consumer acceptance of ornamental fish. In addition to the other inherent characteristics of the species, skin pigmentation is a characteristic that affects its commercial value (Paripatanamont, et al. 1999). Carotenoid (pigment responsible for coloring the skin) can be transported through the food chain through the ingestion of microalgae (Gouveia, et al. 2005). 


\subsection{Rabits}

The search for feeding strategies that aim to increase the nutritional value of rabbit meat as a "functional food", including vitamins, antioxidants and essential fatty acids in the diet (Petracci, et al. 2009), and that are especially of natural origins such as marine microalgae, has been studied in the literature (Peiretti \& Meineiri, 2009). Its use has been shown to have nutraceutical characteristics for these animals and to have effects on the quality of raw and processed meat (Petracci, et al. 2009).

The microalgae Spirulina platensis is cultivated worldwide due to its nutritional characteristics, high concentration of proteins, vitamins, minerals, and its potential therapeutic effect (Colla, et al. 2008). Still, the same authors demonstrated that microalgae have an interesting nutraceutical power by reducing the hypercholesterolemia induced in rabbits, by reducing total cholesterol and increasing serum levels of HDL-cholesterol, considered a protective factor against the development of cardiovascular diseases, as atherosclerosis (Colla, et al. 2008).

Also, to contributing to general health having nutraceutical effects, Spirulina sp. has been used in diets for rabbits and has not shown any adverse effect on the growth performance of these animals (Peiretti \& Meineiri, 2008). The same researchers, in another study on adult rabbits, found that the incorporation of S. platensis in the diet increases the digestibility of crude protein (Peiretti \& Meineri, 2009). In addition, the consumption of microalgae rich in PUFA enriched rabbit meat with these fatty acids (Tassinari, et al. 2002).

The components responsible for these functional properties are believed to be their compounds with potential antioxidants, such as PUFA (mainly EPA and DHA), phycocyanin (Nagaoka, et al. 2005) and phenolic compounds (Miranda, et al. 1998).

DHA and EPA are essential fatty acids for all cells in the body, they play fundamental roles to arise, such as increased metabolism, muscle and cell growth, energy production and oxygen transport, providing adequate nerve functions and hormonal regulation (Wang, et al. 2006).

\section{Final Considerations}

From an environmental perspective, the use of microalgae can benefit environmental protection and natural resource management, specifically the conservation of water and land, as the necessary cultivation areas must be reduced. Microalgae are a promising feed resource that can be used in functional animal feeds. Researches on microalgae supplementation in animal diets could represent a new way to improve human and animal health through better nutrition. The enriched nutritionally valuable constituents, such as $\omega-3$, protein, minerals, vitamins and antioxidant in several species of microalgae are considered a potential natural resource that has been little explored.

In general, the addition of these compounds to the animal diets enhances their overall health and immune status, productivity, and the quality and stability of the animal products. Further investigations into microalga biomass, its active ingredients, and the related biological pathways are needed. Moreover, due to a large number of microalgae species, a complete biochemical characterization is essential to choose the most suitable microalgae for specific feeding technology applications, such as supplements in new animal diets.

\section{References}

Abdelnour, S. A., Abd El-Hack, M. E., Arif, M., Khafaga, A. F. \& Taha, A. E. (2019). The application of the microalgae Chlorella spp. as a supplement in broiler feed. World's Poultry Science Journal, 75(2), 305-318. https://doi.org/10.1017/S0043933919000047

Adarme-Vega, T C., Lim, D. K. Y., Timmins, M., Vernen, F., Li, Y. \& Schenk, P. M. (2012). Microalgae biofactories: a promising approach towards sustainable omega-3 fatty acid production. Microbial Cell Factories, 11(1), 96. https://doi.org/10.1186/1475-2859-11-96 
Ajmone-Cat, M. A., Salvatori, M. L., Simone, R., Mancini, M., Biagioni, S., Bernardo, A. \& Minghetti, L. (2012). Docosahexaenoic acid modulates inflammatory and antineurogenic functions of activated microglial cells. Journal Neuroscience Research, 90(3), 575-587. https://doi.org/10.1002/jnr.22783

Aki, T. K., Hachida, M., Yoshinaga, Y., Katai, T., Yamasaki, T., Kawamoto, S. \& Ono, K. (2003). Thraustochytrid as a potential source of carotenoids. Journal of the American Oil Chemists' Society, 80(8),789-794. https://doi.org/10.1007/s11746-003-0773-2

Altomonte, I., Salari, F., Licitra, R. \& Martini, M. (2018). Use of microalgae in ruminant nutrition and implications on milk quality-A review. Livestock Science, 214, 25-35. https://doi.org/10.1016/j.livsci.2018.05.006

An, B. K., Kim, K. E., Jeon, J. Y. \& Lee, K. W. (2016). Effect of dried CLV vulgaris and CLV growth factor on growth performance, meat qualities and humoral immune responses in broiler chickens. Springer Plus, 5(1), 718. https://doi.org/10.1186/s40064-016-2373-4

An, S. H., Joo, S. S., Lee, H. G., Kim, Z. H., Lee, C. S. Kim, M. \& Kong, C. (2020). Supplementation of Indigenous Green Microalga (Parachlorella sp.) to Pre-starter Diet for Broiler Chickens. Korean Journal of Poultry Science, 47(1), 49-59. https://doi.org/10.5536/KJPS.2020.47.1.49

Andrade, L. M., Andrade, C. J., Dias, M., Nascimento, C. A. O. \& Mendes, M. A. (2018). CLV and Spirulina Microalgae as Sources of Functional Foods, Nutraceuticals, and Food Supplements; an Overview. Food Processing and Technology, 6(1), 00144. https://doi.org/10.15406/mojfpt.2018.06.00144

Appolinário, P. P., Derogis, P. B. M. C., Yamaguti, T. H. \& Miyamoto, S. (2011). Metabolismo, oxidação e implicações biológicas do ácido docosahexaenoico em doenças neurodegenerativas. Química Nova, 34(8), 1409-1416. https://doi.org/10.1590/S0100-40422011000800021

Beauchemin, K. A., M., Kreuzer, F. O. \& McAllister, T. A. (2008). Nutritional management for enteric methane abatement: A review. Australian Journal of Experimental Agriculture, 48(2), 21-27. https://doi.org/10.1071/EA07199

Becker, E. W. (1994). Microalgae: Biotechnology and Microbiology. Vol. 10. Cambridge, UK: Cambridge University Press.

Becker, E. W. (2004). The nutritional value of microalgae for aquaculture. In: Richmond, A. eds Handbook of microalgae mass cultures, 380-391. CRC Press Inc. Boca Raton: Florida.

Becker, E. W. (2007). Micro-algae as a source of protein. Biotechnology Advances, 25(2), 207-210. https://doi.org/10.1016/j.biotechadv.2006.11.002

Bertoldi, F. C., Sant'anna, E. S. \& Oliveira, J. L. B. (2008). Revisão: biotecnologia de microalgas. Boletim do CEPPA, 26(1), 9-20. Retrieved November 24, 2021, from https://www.researchgate.net

Boeckaert, C., Vlaeminck, B., Dijkstra, J. Issa-Zacharia, A., Van Nespen, T., Van Straalen, W. \& Fievez, V. (2008). Effect of Dietary Starch or Micro Algae Supplementation on Rumen Fermentation and Milk Fatty Acid Composition of Dairy Cows. Journal Dairy Science, 91(12), 4714-4727. https://doi.org/10.3168/jds.2008-1178

Brasky, T. M., Lampe, J. W., Potter, J. D., Patterson, R. E. \& White, E. (2010). Specialty supplement and breast cancer risk in the vita-min and lifestyle (VITAL) cohort. Cancer Epidemiology and Prevention Biomarkers, 19(7), 1696-1708. https://doi.org/10.1158/1055-9965.EPI-10-0318

Carrillo, S., Lopez, E., Casas, M. M., Avila, E., Castillo, R. M., Carranco, M. E. \& Pérez-Gil, F. (2008). Potential use of seaweeds in the laying hen ration to improve the quality of n-3 fatty acid enriched eggs. Journal Applied Phycology, 20, 271-278. https://doi.org/10.1007/978-1-4020-9619-8_34

Chang, G., Luo, Z., Gu, S., Wub, Q., Chang, M. \& Wang, X. (2013). Fatty acid shifts and metabolic activity changes of Schizochytrium sp. S31 cultured on glycerol. Bioresource Technology, 142, 255-260. https://doi.org/10.1016/j.biortech.2013.05.030

Chew, K. W., Yap, J. Y., Show, P. L., Suan, N. H., Juan, J. C., Ling, T. C. \& Chang, J. S. (2017). Microalgae biorefinery: high value products perspectives. Bioresource Technology, 229, 53-62. https://doi.org/10.1016/j.biortech.2017.01.006

Choi, H., Jung, S. K., Kim, J. S Kim, K. W., Oh, K. B., Lee, P. Y. \& Byun, S. J. (2017). Effects of dietary recombinant CLV supplementation on growth performance, meat quality, blood characteristics, excreta microflora, and nutrient digestibility in broilers. Poultry Science, 96(3), 710-716. https://doi.org/10.3382/ps/pew345

Christaki, E., Florou-Paneri, P. \& Bonos, E. (2011). Microalgae: a novel ingredient in nutrition. International Journal of Food Sciences and Nutrition, 62(8), 794-799. https://doi.org/10.3109/09637486.2011.582460

Colla, L. M., Maccillo-Baisch, A. L. \& Costa, J. A. (2008). Spirulina platensis effects of the levels of total cholesterol, HDL and triacylglycerols in rabbits fed with a hypercholesterolemic diet. Brazilian Archives of Biology and Technology, 51, 35-43.

Silva, G. G., de Jesus, E. F., Takiya, C. S., Del Valle, T. A., da Silva, T. H., Vendramini, T. H. A. \& Rennó, F. P. (2016). Partial replacement of ground corn with algae meal in a dairy cow diet: Milk yield and composition, nutrient digestibility, and metabolic profile. Journal of Dairy Science, 99(11), 8880-8884. https://doi.org/10.3168/jds.2016-11542

Rivera, C., Boutet, I., Zicker, C. S. \& Milgram, N. W. (2005). A novel method for assessing contrast sensitivity in the beagle dog is sensitive to age and an antioxidant enriched food. Progress in Neuro-Psychopharmacology and Biological Psychiatry, 29(3), 379-387. https://doi.org/10.1016/j.pnpbp.2004.12.004

Drewery, M. L., Sawyer, J. E., Pinchak, W. E. \& Wickersham, T. A. (2014). Effect of increasing amounts of postextraction algal residue on straw utilization in steers. Journal of Animal Science, 92(10), 4642-4649. https://doi.org/10.2527/jas.2014-7795

El-Bahr, S., Shousha, S., Shehab, A., Khattab, W., Ahmed-Farid, O., Sabike, I. \& Albosadah, K. (2020). Effect of Dietary Microalgae on Growth Performance, Profiles of Amino and Fatty Acids, Antioxidant Status, and Meat Quality of Broiler Chickens. Animals, 10(5), 761. https://doi.org/10.3390/ani10050761

Fabregas, J. \& Herrero, C. (1990). The potential use of marine microalgae as source of vitamins in nutrition. Journal of Industrial Microbiology, 5(4), 259264. https://doi.org/10.1007/BF01569683 
Fievez, V., Dohme, F., Danneels, M., Raes, K. \& Demeyer, D. (2003). Fish oils as potent rumen methane inhibitors and associated effects on rumen fermentation in vitro and in vivo. Journal Animal Science and Technology, 104(1-4), 41-58. https://doi.org/10.1016/S0377-8401(02)00330-9

Franklin, S. T., Martin, K. R., Baer, R. J., Schingoeth, D. J. \& Hippen, A. R. (1999). Dietary marine algae (Schizochytrium sp.) increases concentrations of conjugated linoleic, docosahexaenoic and transvaccenic acids in milk of dairy cows. Jornal of Nutrition, 129(11), 2048-2054. https://doi.org/10.1093/jn/129.11.2048

Gouveia, L., Choubert, G., Gomes, E., Rema, P. \& Empis, J. (1998). Use of Chlorella vulgaris as a carotenoid source for salmonids: effect of dietary lipid content on color, digestibility and muscle retention. Aquaculture International, 6, 269-279. https://doi.org/10.1023/A:1009251714573

Gouveia, L., Choubert, G., Gomes, E., Pereira, N. \& Santinha, J. (2002). Empis Colouringation of gilthead seabream, Sparus aurata (Lin 1875), using Chlorella vulgaris microalga. Aquaculture Research, 33(12), 1-7. https://doi.org/10.1046/j.1365-2109.2002.00751.x

Gouveia, L., Rema, P., Pereira, O. \& Empis, J. (2003). Colouring ornamental fish (Cyprinus carpio e Carassius auratus) with microalgal biomasss. Aquaculture Nutrition, 9(2), 123-129. https://doi.org/10.1046/j.1365-2095.2003.00233.x

Gouveia, L., Batista, A. P., Sousa, I., Raymundo, A. \& Bandarra, N. M. (2008). Microalgae in novel food products. In K. Papadoupoulos, Food Chemistry Research Developments, 75-112. New York: Nova Science Publishers.

Grigorova, S., Surdjiiska, S., Banskalieva, V. \& Dimitrov, G. (2006). The effect of biomass from green algae of Chlorella genus on the biochemical characteristics of table eggs. Journal of Central European Agriculture, 7(1), 111-116.

Grinstead, G. S., Tokach, M. D., Dritz, S. S, Goodband, R. D. \& Nelssen, J. L. (2000). Effects of Spirulina platensis on growth performance of weanling pigs. Animal Feed Science and Technology, 83(4), 237-247. https://doi.org/10.1016/S0377-8401(99)00130-3

Hadley, K. B., Bauer, J. \& Milgram, N. W. (2017). The oil-rich alga Schizochytrium sp. as a dietary source of docosahexaenoic acid improves shape discrimination learning associated with visual processing in a canine model of senescence. Prostaglandins, Leukotrienes and Essential Fatty Acids, 118, 10 18. https://doi.org/10.1016/j.plefa.2017.01.011

Hakin, A. R. (2012). The potential of heterotrophic microalgae (Schizochytrium sp.) as a source of DHA. Bulletin of Marine and Fisheries Postharvest and Biotechnology, 7(1), 29-38.

Heinemann, K. M., Waldron, M. K., Bigley, K. E., Lees, G. E. \& Bauer, J. E. (2005). Lon- g-chain (n-3) polyunsaturated fatty acids are more efficient than alpha-linolenic acid in improving ectroretinogram responses of puppies exposed during gestation, lactation, and weaning. Journal of Nutrition, 135(8), 1960. https://doi.org/10.1093/jn/135.8.1960

Hong, W. K., RAirakhwada, D., Seo, P. S., Park, S. Y., Hur, B. K., Kim, C. H. \& Seo, J. W. (2011). Production of lipids containing high levels of docosahexaenoic acid by a newly isolated microalga, Aurantiochytrium sp. KRS101. Applied Biochemistry and Biotechnology, 164(8), 1468-1480. https://doi.org/10.1007/s12010-011-9227-x

Keegan, J. D., Currie, D., Knox, A. \& Moran, C. A. (2019). Redressing the balance: Including DHA-rich Aurantiochytrium limacinum in broiler diets increases tissue omega-3 fatty acid content and lowers the $\mathrm{n}-6: \mathrm{n}-3$ ratio. British Poultry Science, 60(4), 414-422. https://doi.org/10.1080/00071668.2019.1605153

Koller, M., Alexander, M. \& Gerhart, B. (2014). "Microalgae as versatile cellular factories for valued products." Algal research, 6, 52-63. https://doi.org/10.1016/j.algal.2014.09.002

Kotrbáček, V., Doubek, J. \& Doucha, J. (2015). The chlorococcalean alga CLV in animal nutrition: A review. Journal of Applied Phycology, 27(6), 21732180. https://doi.org/10.1007/s10811-014-0516-y

Kouba, A., Sales, J., Sergejevová, M., Kozák, P. \& Masojídek, J. (2013). Colour intensity in angelfish (p terophyllum scalare) as influenced by dietary microalgae addition. Journal of Applied Ichthyology, 29(1), 193-199. https://doi.org/10.1111/jai.12010

Kouřimská, L., Vondráčková, E., Fantová, M., Nový, P., Nohejlová, L. \& Michnov, K. (2014). Effect of feeding with algae on fatty acid profile of goat's milk. Scientia Agricuturae Bohemica, 45(3), 162-169. https://doi.org/10.2478/sab-2014-0103

Lamminen, M., Halmemies-Beauchet-Filleau, A., Kokkonen, T., Simpura, I., Jaakkola, S. \& Vanhatalo, A. (2017). Comparison of microalgae and rapeseed meal as supplementary protein in the grass silage based nutrition of dairy cows. Animal Feed Science and Technology, 234, 295-311. https://doi.org/10.1016/j.anifeedsci.2017.10.002

Lemahieu, C., Bruneel, C., Verhalle, R. T., Muyhaert, K., Buyse, J. \& Foubert, I. (2013). Impact of feed supplementation with different omega-3 rich microalgae species on enrichment of eggs of laying hens. Food Chemistry, 141(4), 4051-4059. https://doi.org/10.1016/j.foodchem.2013.06.078

Li, H. B., Cheng, K. W., Wong, C. C., Fan, K. W., Chen, F. \& Jiang, Y. (2007). Evaluation of antioxidant capacity and total phenolic content of different fractions of selected microalgae. Food Chemistry, 102(3), 771-776. https://doi.org/10.1016/j.foodchem.2006.06.022

Marriott, N. G., Garrett, J. E., Sims, M. D. \& Abril, J. R. (2002). Características de desempenho e composição de ácidos graxos de suínos alimentados com dieta contendo ácido docosahexaenóico. Journal of Muscle Foods, 13(4), 265-277. https://doi.org/10.1111/j.1745-4573.2002.tb00335.x

Mason, R. (2001). CLV and Spirulina: Green supplements for balancing the body. Alternative and Complementary Therapies, 7(3), $161-165$.

Mccusker, S., Buff, P. R., Yu, Z. \& Fascetti, A. J. (2014). Amino acid contento f selected plant, algal and insect species: a search for alternative protein sources for use in pet foods. Journal of Nutrition Science, 3, 1-5. https://doi.org/10.1017/jns.2014.33

Miranda, M. S., Cintra, R. G., Barros, S. B. M. \& Filho, J. M. (1998). Antioxidant activity of the microalga Spirulina maxima. Brazilian Journal of Medical and Biological Research, 31(8), 1075-1079. https://doi.org/10.1590/S0100-879X1998000800007 
Moate, P. J., Williams, S. R. O., Grainger, C., Hannah, M. C., Ponnampalam, E. N. \& Eckard, R. J. (2011). Influence of cold-pressed canola, brewers grains and hominy meal as dietary supplements suitable for reducing enteric methane emissions from lactating dairy cows. Animal Feed Science and Technology, 166, 254-264. https://doi.org/10.1016/j.anifeedsci.2011.04.069

Moate, P. J., Williams, S. R. O., Hannah, M. C., Eckard, R. J., Auldist, M. J., Ribaux, B. E. \& Wales, W. J. (2013). Effects of feeding algal meal high in docosahexaenoic acid on feed intake, milk production, and methane emissions in dairy cows. Journal Dairy Science, 96(5), 3177-3188. https://doi.org/10.3168/jds.2012-6168

Nagaoka, S., Shimizu, K., Kaneko, H., Shibayama, F., Morikawa, K., Kanamaru, Y. \& Kato, T. (2005). A novel protein C-phycocyanin plays a crucial role in the hypocholesterolemic action of Spirulina platensis concentrate in rats. Journal of Nutrition, 135, 2425-2430. https://doi.org/10.1093/jn/135.10.2425

Nandeesha, M. C., Gangadhara, B., Manissery, J. K. \& Venkataraman, L.V. (2001). Growth performance of two Indian major carps, catla (Catlacatla) and rohu (Labeorohita) fed diets containing different levels of Spirulina platensis. Bioresource Technology, 80(2), 117-120. https://doi.org/10.1016/S09608524(01)00085-2

Natrah, F., Yosoff, F. M., Shariff, M., Abas, F. \& Mariana, N. S. (2007). Screening of Malaysian indigenous microalgae for antioxidant properties and nutritional value. Journal of Applied Phycology, 19(6), 711-718. https://doi.org/10.1007/s10811-007-9192-5

Neto, J. M. C., Teixeira, R. G., Cavalcanti de Sá, M. J., Lima, A. E., Jacinto-Aragão, G. S., Teixeira, M. W. \& de Azevedo, A. S. (2010). Farinha de algas marinhas (Lithothamnium calcareum) como suplemento mineral na cicatrização óssea de autoenxerto cortical em cães. Revista Brasileira de Saúde e Produção Animal, 11(1), 217-230.

Oh, S. T., Zheng, L., Kwon, H. J., H. J., Choo, Y. K., Lee, K. W., Kang, C. W. \& An, B. K. (2015). Effects of dietary fermented CLV vulgaris (CBT®) on growth performance, relative organ weights, cecal microflora, tibia bone characteristics, and meat qualities in Pekin ducks. Asian-Australasian. Journal of Animal Sciences, 28(1), 95-101. https://doi.org/10.5713/ajas.14.0473

Or-Rashid, M. M., Krame, J. K. G., Wood, M. A. \& McBride, B. W. (2008). Supplemental algal meal alters the ruminal trans-18:1 fatty acid and conjugated linoleic acid composition in cattle. Journal of Animal Science, 86(1), 187-196. https://doi.org/10.2527/jas.2007-0085

Papadopoulos, B. G., Goulas, C., Apostolaki, E. \& Abril, R. (2002). Effects of dietary supplements of algae, containing polyunsaturated fatty acids, on milk yield and the composition of milk products in dairy ewes. The Journal of Dairy Research, 69(3), 357-365. https://doi.org/10.1017/S0022029902005599

Palmegiano, G. B., Agradi, E., Forneris, G., Gai, F., Gasco, L., Rigamonti, E. \& Zoccarato, I. (2005). Spirulina as a nutrient source in diets for growing sturgeon (Acipenser baeri). Aquaculture Research, 36(2), 188-195. https://doi.org/10.1111/j.1365-2109.2005.01209.x

Paripatanamont, T., Tangtrongpairoj, J., Sailasuta, A. \& Chansue, N. (1999). Effect of astaxanthin on the pigmentation of goldfish Carassius auratus. Journal of the World Aquaculture Society, 30(4), 454-460. https://doi.org/10.1111/j.1749-7345.1999.tb00993.x

Peiretti, P. G. \& Meineri, G. (2009). Effects of two antioxidants on the morpho-biometrical parameters, apparent digestibility and meat composition in rabbits fed low and high fat diets. Journal of Animal and Veterinary Advances, 8(11), 2299-2304.

Peiretti, P. G. \& Meineri G. (2008). Effects of diets with increasing levels of Spirulina platensis on the performance and apparent digestibility in growing rabbits. Livestock Science, 118, 173-177. https://doi.org/10.1016/j.livsci.2008.04.017

Pestana, J. M., Puerta, B., Santos, H., Madeira, M. S., Alfaia, C. M., Lopes, P. A. \& Prates, J. A. M. (2020). Impact of dietary incorporation of Spirulina (Arthrospira platensis) and exogenous enzymes on broiler performance, carcass traits, and meat quality. Poultry Science, 99, 2519-2532. https://doi.org/10.1016/j.psj.2019.11.069

Petracci, M. Bianchi, C. \& Cavani, C. (2009). Development of rabbit meat products fortified with n-3 polyunsaturated fatty acids. Nutrients, 1(2), 111-118. https://doi.org/10.3390/nu1020111

Petrolli, T. G., Petrolli, O. J., Pereira, A. S. C., Zotti, C. A., Romani, J., Villani, R. \& Zanandréa, F. M. (2019). Effects of the Dietary Supplementation with a Microalga Extract on Broiler Performance and Fatty-Acid Meat Profile. Brazilian Journal of Poultry Science, 21(3), 1-7. https://doi.org/10.1590/1806-9061$2018-0958$

Pikitch, E., Boersma, P. D., Boyd, I., Conover, D., Cury, P., Essington, T. \& Steneck, R. (2012). Little fish, big impact: managing a crucial link in ocean food webs. Lenfest Ocean Program, 108p. Washington, DC.

Póti, P., Pajor, F., Bodnár, Á., Penksza, K. \& Köles, P. (2015). Effect of micro-alga supplementation on goat and cow milk fatty acid composition. Jornal Chileno de Pesquisa Agrícola, 75(2), 259-263. https://dx.doi.org/10.4067/S0718-58392015000200017

Pulz, O. \& Gross, W. (2004). Valuable products from biotechnology of microalgae. Applied Microbiology and Biotechnology, 65(6), 635-648. https://doi.org/10.1007/s00253-004-1647-x

Roy, S. S. \& Pal, R. (2015). Microalgae in aquaculture: a review with special references to nutritional value and fish dietetics. In Proceedings of the Zoological Society, 68(1), 1-8. https://doi.org/10.1007/s12595-013-0089-9

Santos, S. K. A., Moura, G. S., Pedreira, M. M., Prates, A. D. S. \& Ferreira, A. L., Azevedo, R. C. (2015). Microalga Schizochytrium sp. em Rações para Tilápia do Nilo. Caderno de Ciências Agrárias, 7, 75-79.

Sardi, L., Martelli, G., Lambertini, L., Parisini, P. \& Mordenti, A. (2006). Effects of a dietary supplement of DHA-rich marine algae on Italian heavy pig production parameters. Livestock Science, 103(2), 95-103. https://doi.org/10.1016/j.livsci.2006.01.009

Sarker, P. K., Gamble, M. M., Kelson, S. \& Kapuscinski, A. R. (2016). Nile tilapia (Oreochromis niloticus) show high digestibility of lipid and fatty acids from marine $S$ chizochytrium sp. and of protein and essential amino acids from freshwater Spirulina sp. feed ingredients. Aquaculture Nutrition, 22(1), 109119. https://doi.org/10.1111/anu.12230 
Sete, M. R. C. \& Figueredo, C. M. S. (2013). Periodontitis and omega-3: the role of fatty acids in the inflammatory process. Revista Hospital Universitário Pedro Ernesto, 12(1), 58-65. https://doi.org/10.12957/rhupe.2013.8804

Sheibel, S. (2016). Propriedades funcionais do ácido docosahexaenoico (DHA) para gatos. Dissertação (Mestrado em Zootecnia) Universidade Estadual de Maringá, UEM, Maringá.

Simopoulos, A. P. (2002). The importance of the ratio of omega-6/omega-3 essential fatty acids. Biomedicine \& Pharmacotherapy, 56(8), 365-379. https://doi.org/10.1016/S0753-3322(02)00253-6

Šimkus, A., Šimkienè, A., Černauskienė, J., Kvietkutè, N., Černauskas, A., Paleckaitis, M. \& Kerzienė, S. (2013). The effect of blue algae Spirulina platensis on pig growth performance and carcass and meat quality. Veterinarija in Zootechnika, 61(83), 70-74.

Smith, A. D. M., Brown, C. J., Bulman, C. M., Fulton, E. A., Johnson, P., Kaplan, I. C. \& Tam, J. (2011). Impacts of fishing low trophic level species on marine ecosystems. Science, 33(6046), 1147-1150. https://doi.org/10.1126/science.1209395

Soster, T., Lima, M. O. \& Cella, P. S. (2018). Effect of functional oils and algae on the performance of piglets in the initial phase. Scientific Electronic Archives, 11(3), 32-35. https://doi.org/10.36560/1132018576

Souza, C. M. M., de Lima, D. C., Bastos, T. S., de Oliveira, S. G., Beirão, B. C. B. \& Félix, A. P. (2019). Microalgae Schizochytrium sp. as a source of docosahexaenoic acid (DHA): Effects on diet digestibility, oxidation and palatability and on immunity and inflammatory indices in dogs. Animal Science Journal, 90(12), 1567-1574. https://doi.org/10.1111/asj.13294

Souza, C. M. M., de Lima, D. C., Bastos, T. S., Komarcheuski, A. S., de Oliveira, S. G. \& Félix, A. P. (2020). The effect of supplementation of microalgae Schizochytrium sp. as a source of docosahexaenoic acid (DHA) on dogs with naturally occurring gingivitis. Archives of Veterinary Science, 25(1), 80-86. http://dx.doi.org/10.5380/avs.v25i1.62680

Sun, X., Chang, Y., Ye, Y., Ma, Z., Liang, Y. \& Li, T. (2012). The effect of dietary pigments on the coloration of Japanese ornamental carp (koi, Cyprinus carpio L.). Aquaculture, 342, 62-68. https://doi.org/10.1016/j.aquaculture.2012.02.019

Spolaore, P., Joannis-Cassan, C., Duran, E. \& Isambert, A. (2006). Commercial applications of microalgae. Journal of Bioscience and Bioengineering, 101(2), 87-96. https://doi.org/10.1263/jbb.101.87

Stamey, J. A., Shepherd, D. M., de Veth, M. J. \& Corl, B. A. (2012). Use of algae or algal oil richin n-3 fatty acids as a feed supplement for dairy cattle. Journal of Dairy Science, 95(9), 5269-5275. https://doi.org/10.3168/jds.2012-5412

Stoeckel, K., Nielsen, L. H., Fuhrmann, H. \& Bachmann, L. (2011). Fatty acid patterns of dog erythrocyte membranes after feeding of a fish-oil based DHArich supplement with a base diet low in n-3 fatty acids versus a diet containing added n-3 fatty acids. Acta Veterinaria Scandinavica, 53(1), 1-11. https://doi.org/10.1186/1751-0147-53-57

Stokes, R. S., Van Emon, M. L., Loy, D. D. \& Hansen, S. L. (2015). Assessment of algae meal as a ruminant feedstuff: Nutrient digestibility in sheep as a model species. Journal Animal Science, 93(11), 5386-5394. https://doi.org/10.2527/jas.2015-9583

Svircev, Z. (2005). Mikroalge i cijanobakterije u biotehnologiji. Novi Sad: Prirodno matematički fakultet.

Tassinari, M., Mordenti, A. L., Testi, S. \& Zotti, A. (2002). Esperienze sulla possibilita` di arricchire con la dieta la carne di coniglio di LCPUFA n-3. Progress in Nutrition, 4(2), 119-124.

Toral, P. G., Belenguer, A., Shingfield, K. J., Hervás, G., Toivonen, V. \& Frutos, P. (2012). Fatty acid composition and bacterial community changes in the rumen fluid of lactating sheep fed sunflower oil plus incremental levels of marine algae. Journal of Dairy Science, 95(2), 794-806. https://doi.org/10.3168/jds.2011-4561

Tsiplakou, E., Abdullah, M. A. M., Mavrommatis, A., Chatzikonstantinou, M., Skliros, D., Sotirakoglou, K. \& Zervas, G. (2018). The effect of dietary Chlorella vulgaris inclusion on goats milk chemical composition, fatty acids profile and enzymes activities related to oxidation. Journal Animal Physiology and Animal Nutrition, 102(1), 142-150. https://doi.org/10.1111/jpn.12671

Van Emon, M. L., Loy, D. D. \& Hansen, S. L. (2015). Determining the preference, in vitro digestibility, in situ disappearance, and grower period performance of steers fed a novel algae meal derived from heterotrophic microalgae. Journal Animal Science, 93(6), 3121-3129. https://doi.org/10.2527/jas.2014-8654

Venckus, P., Kostkevičienè, J. \& Bendikienè, V. (2017). Green algae Chlorella vulgaris cultivation in municipal wastewater and biomass composition. Journal of Environmental Engineering and Landscape Management, 25(1), 56-63. https://doi.org/10.3846/16486897.2016.1245661

Wallace, F. A., Miles, E. A. \& Calder, P. C. (2003). Comparison of the effects of linseed oil and different doses of fish oil on mononuclear cell function in healthy human subjects. British Journal of Nutrition, 89(5), 679-89. https://doi.org/10.1079/BJN2002821

Wang, C., Harris, W. S., Chung, M., Lichtenstein, A. H., Balk, E. M., Kupelnick, B., Jordan, H. S. \& Lau, J. (2006). n-3 Fatty acids from fish or fish-oil supplements, but not $\alpha$-linolenic acid, benefit cardiovascular disease outcomes in primary- and secondary-prevention studies: a systematic review. The American Journal of Clinical Nutrition, 84(1), 5-17. https://doi.org/10.1093/ajcn/84.1.5

Wu, Y. B., Li, L., Wen, Z. G., Yan, H. J., Yang, P. L., Tang, J. \& Hou, S. S. (2019). Dual functions of eicosapentaenoic acid-rich microalgae: enrichment of yolk with n-3 polyunsaturated fatty acids and partial replacement for soybean meal in diet of laying hens. Poultry Science, 98(1), 350-357. https://doi.org/10.3382/ps/pey372

Zheng, L., Oh, S. T., Jeon, J. Y., Moon, B. H., Kwon, H. S., Lim, S. U. \& Kang, C. W. (2012). The dietary effects of fermented CLV vulgaris (CBT) on production performance, liver lipids and intestinal microflora in laying hens. Asian-Australian Journal of Animal Science, 25(2), 261-266. https://doi.org/10.5713/ajas.2011.11273 